\title{
Standing on Firmer Ground: Separation of Powers and Deference to Congressional Findings in the Standing Analysis
}

\author{
Christopher J. Sprigman†
}

Suppose that you live near a coal-fired power plant. You worry about the health effects of the soot that falls on your neighborhood. Determined to do something, you write to your Congressman. Somehow, it works. Congress passes a law that requires particulate emissions from coal-fired plants to be halved within one year. The law, however, does not specify how particulate emissions are to be measured. Instead, Congress directs the Environmental Protection Agency to determine which measuring technology is "the most effective" and to mandate its use through rulemaking.

The electric utilities and the coal industry see their chance. They encourage EPA to adopt a cheap, outdated measuring technology that cannot detect certain harmful particulates. You object, arguing that the statute compels EPA to choose "the most effective" measuring technique-not an outdated, ineffective one, or even the one most cost effective. EPA rules against you. So you sue the agency, alleging that they abused their discretion under the statute. You have a strong case on the merits. Before your arguments are heard, however, you must have standing to sue. In this case, whether you have standing boils down to two questions: (1) did EPA's ruling cause your injury? and (2) can the court do anything to redress your injury? At first glance, these questions appear simple. But if a court overturns EPA's ruling, the plant's operators may not comply with the order, choosing instead to exceed the particulate emissions standard and pay fines. If so, is your injury redressed? Similarly, the level of exposure to particulate emissions required to cause injury may be uncertain. If so, at what point does EPA's ruling make a difference significant enough to rise to "causation?"

This Comment explores a solution to these questions based on congressional factinding. Congress makes findings of fact as part

$\dagger$ B.A. 1988, University of Pennsylvania; J.D. Candidate 1993, The University of Chicago. 
of the legislative process. Often, Congress's findings address facts relevant to causation and redressability. In the example outlined above, Congress may have found that power companies would comply with emissions limits rather than pay fines. Or, based on scientific reports, Congress may have established a safe exposure limit for particulate emissions.

Despite the potential to simplify the standing inquiry by deferring to relevant factual findings made by Congress, the D.C. Circuit has divided deeply over what role congressional findings should play in a court's standing inquiry. In a series of cases since 1988, one wing of the court, fearful that deference to congressional findings in the standing analysis might encourage illegitimate congressional expansion of the Article III judicial power, argues for de novo review of causation and redressability. Another wing maintains that courts should defer to rationally based congressional findings that address causation and redressability. Both wings of the D.C. Circuit ground their arguments in particular conceptions of separation of powers.

This Comment is organized in three parts. Part I reviews current standing law and explores its shortcomings. Part II examines the D.C. Circuit's decision in Center for Auto Safety v Thomas, ${ }^{1}$ where the debate over deference to congressional findings began, and traces the development of the issue in three subsequent D.C. Circuit cases: Dellums v Nuclear Regulatory Comm'n, ${ }^{2}$ United Transportation Union v Interstate Commerce Comm'n, ${ }^{3}$ and City of Los Angeles v National Highway Traffic Safety Admin. ${ }^{4}$ Using these cases as a framework, Part III argues that separation of powers considerations compel deference to congressional findings on facts underlying causation and redressability. ${ }^{5}$

Much academic commentary has criticized standing analysis or advocated a less restrictive doctrine. ${ }^{6}$ The Supreme Court, however, has shown no inclination to abandon its current approach.

1847 F2d 843 (DC Cir 1988), vacated on other grounds, 856 F2d 1557 (DC Cir 1988).

2863 F2d 968 (DC Cir 1988).

3 891 F2d 908 (DC Cir 1989).

+ 912 F2d 478 (DC Cir 1990).

- This Comment covers only cases from the D.C. Circuit, because that circuit hears most private plaintiff suits against administrative agencies. Nevertheless, the case law from other circuits does not change this Comment's substantive arguments.

${ }^{-}$See, for example, Gene R. Nichol, Jr., Abusing Standing: A Comment on Allen v. Wright, $133 \mathrm{U}$ Pa L Rev 635, 642-49 (1985) (criticizing use of separation of powers analysis in current standing doctrine); Note, The Supreme Court, 1983 Term-Leading Cases, 98 Harv L Rev 87, 241-46 (1984) (criticizing the Court for not clarifying standing doctrine to specify what types of separation of powers issues should trigger the stricter causality .re- 
This Comment does not propose a new framework for standing analysis. Rather, it shows how deference to legislative findings makes the present standing test more useful.

\section{Misunderstanding Standing: The Supreme Court's CONFUSED JURISPRUDENCE ${ }^{7}$}

A party has standing to sue when she "has a sufficient stake in an otherwise justiciable controversy to obtain judicial resolution of that controversy." 8 In Justice Scalia's no-nonsense phraseology, the standing inquiry boils down to the equivalent of " $[\mathrm{w}]$ hat's it to you?"'

\section{A. The Rise, Fall, and Rise of Private-Law Standing}

Two decades ago the Court's standing test required that plaintiffs press a common law or statutory cause of action. ${ }^{10}$ The "gist of the question of standing," according to Flast $v$ Cohen, ${ }^{11}$ decided in the last year of the Warren Court, was whether the litigant's personal stake in the controversy ensured "that concrete adverseness which sharpens the presentation of issues upon which the court so largely depends for illumination of difficult constitutional questions."

This private-law model offered simplicity, but it sharply limited private plaintiff suits against administrative agencies, which are public-law entities. Plaintiffs were required to press a recognized "nineteenth century private right"-i.e., an agency action that invaded a common law or statutory right. ${ }^{12}$ Agency inaction was not justiciable. ${ }^{13}$ As the private-law regime often worked out in

quirement); Mark V. Tushnet, The Sociology of Article III: A Response to Professor Brilmayer, 93 Harv L Rev 1698 (1980) (arguing for a less restrictive standing doctrine).

7 Apologies to Professor Currie. See David P. Currie, Misunderstanding Standing, 1981 Sup Ct Rev 41.

- Sierra Club v Morton, 405 US 727, 731 (1972).

- Antonin Scalia, The Doctrine of Standing as an Essential Element of the Separation of Powers, 17 Suffolk U L Rev 881, 882 (1983).

10 See Laurence Tribe, American Constitutional Law $\$ 3-14$ at 108 (Foundation, 1988) (asserting that the Court's former concern was directed toward avoiding advisory opinions).

21 392 US 83, 99 (1968), quoting Baker v Carr, 369 US 186, 204 (1962).

12 See Cass R. Sunstein, Standing and the Privatization of Public Law, 88 Colum L Rev 1432, 1433 (1988).

1s See, for example, Linda R.S. $v$ Richard D., 410 US 614, 619 (1973) (holding that a private citizen cannot contest a prosecutor's decision not to prosecute). See also Heckler $v$ Chaney, 470 US 821, 832 (1985) (holding agency inaction presumptively unreviewable). 
practice, only regulated entities-not actual or potential regulatory beneficiaries-could sue to enforce public-law rights. ${ }^{14}$

In time, the private-law model of standing came into conflict with the public-law aspirations of the New Deal administrative state. The rise of administrative agencies as a headless "fourth branch" of government led to increased regulation by unelected officials of our economic, social, and political lives. ${ }^{15}$ Alongside its sweeping delegations to regulatory agencies, however, Congress sought to balance the newly created administrative agency power with public-law causes of action through devices such as the Administrative Procedure Act. ${ }^{16}$ Nevertheless, the private-law standing model systematically barred public-law plaintiffs from the courts. ${ }^{17}$

This created an important separation of powers issue. Administrative agencies present an imperfect democratic pedigree-they exercise considerable power, yet are not directly answerable to voters. By this view, private plaintiff suits are an important restraint on agency discretion. However, the requirement of private-law standing prevented judicial enforcement of public-law rights. The power of administrative agencies over potential public-law plaintiffs remained unchecked.

The Burger Court's initial reconceptualization of standing attempted to reconcile pre-New Deal separation of powers with the modern administrative state. ${ }^{18}$ First, the Burger Court dramatically altered the focus of the standing inquiry. In Ass'n of Data Processing Service Organizations v Camp, the Court replaced the common law legal interest test with a factual inquiry into whether plaintiffs' claims were "arguably within the zone of interests" protected by the statute or constitutional provision at issue. ${ }^{19}$ This new "zone of interests" test sought to reestablish separation of powers by providing relatively easy access to the courts for regulatory objects and beneficiaries. Data Processing, however, was the high water mark of the post-New Deal standing model. In a retreat

\footnotetext{
14 Sunstein, 88 Colum L Rev at 1432 (cited in note 12).

${ }^{15}$ See Federal Trade Comm'n v Ruberoid Co., 343 US 470, 487 (1952) (Jackson dissenting).

${ }^{16} 5$ USC \& 702 (1988).

${ }^{17}$ See, for example, Simon v Eastern Kentucky Welfare Rights Organization ("EKWRO"), 426 US 26, 42-43 (1976) (denying standing to indigents seeking to use the Administrative Procedure Act to challenge a tax ruling that decreased hospitals' incentives to provide medical services to the poor).

${ }^{18}$ See Sunstein, 88 Colum L Rev at 1432 (cited in note 12).

19397 US 150, 153 (1970). See also Sunstein, 88 Colum L Rev at 1445.
} 
from the pure "zone of interests" test, the Court subsequently introduced causation and redressability requirements into the standing analysis. ${ }^{20}$

B. Modern Article III Standing: The Re-emergence of PrivateLaw Standing in a Public-Law State

Modern standing law is rooted in Article III of the Constitution, which limits the judicial power to "cases or controversies." The purpose of standing is not just to ensure that plaintiffs have a cause of action, but to prevent litigants from "drawing federal courts into unnecessary conflict with coordinate branches."22 Separation of powers, then, has been a constant theme pervading modern standing law. ${ }^{23}$

The present Article III standing test, as articulated by Justice Rehnquist in Valley Forge Christian College $v$ Americans United for Separation of Church and State, ${ }^{24}$ requires that the plaintiff show, as an "irreducible minimum": (1) "that he personally has suffered some actual or threatened injury as a result of the putatively illegal conduct of the defendant," (injury-in-fact); (2) that the injury "fairly can be traced to the challenged action," (causation); and (3) that the injury "is likely to be redressed by a favorable decision" (redressability). ${ }^{25}$

Congress, acting alone, can establish injury-in-fact. ${ }^{26}$ For example, if Congress finds that "being subject to particulate emissions from power plants is an injury under federal law," courts will not make a factual inquiry into whether people are actually hurt

\footnotetext{
20 See Allen $v$ Wright, 468 US 737, 750-52 (1984); EKWRO, 426 US at 37-39; Warth $v$ Seldin, 422 US 490, 498-501 (1975).

21 See US Const, Art III, $\S 2$, cl 1.

${ }_{22}$ Tribe, American Constitutional Law $\$ 314$ at 109 (cited in note 10). The desire to avoid advisory opinions itself implicates separation of powers concerns.

${ }^{23}$ The standing doctrine is, according to Justice O'Connor, "built on a single basic idea-the idea of separation of powers." Allen, 468 US at 752.

24 454 US 464 (1982).

25 Id at 472 (citations omitted).

28 The Supreme Court recently created a small caveat in Lujan v Defenders of Wildlife, $112 \mathrm{~S} \mathrm{Ct} 2130$ (1992). In Lujan, the Court held that the citizen suit provision of the Endangered Species Act, 16 USC $\$ 1540(\mathrm{~g})$ (1988), did not permit private suits by plaintiffs who asserted only a generalized grievance indistinguishable from the public's interest in the proper administration of the laws. The Court maintained, however, that nothing in Lujan contradicted the principle that " $[t]$ he ... injury required by Art. III may exist solely by virtue of statutes creating legal rights, the invasion of which creates standing. ... [Statutory] broadening [of] the categories of injury that may be alleged in support of standing is a different matter from abandoning the requirement that the party seeking review must himself have suffered an injury." Id at 2145-46 (citations omitted).
} 
by particulates. Moreover, even if Congress has not spoken directly to the injury at issue, Data Processing still assures that injuries "arguably within the zone of interests" protected by a statute or constitutional provision meet the injury-in-fact requirement. ${ }^{27}$

By contrast, courts often treat causation and redressability as purely factual questions. If Congress finds that "power companies will comply with limits on particulate emissions, rather than pay fines," courts may nevertheless inquire into the truth of this assertion. ${ }^{28}$ It is unclear why courts that are skeptical on causation and redressability are simultaneously deferential on injury-in-fact. Even if the distinction makes sense, a judicial method for inquiring into the truth of congressional findings pertaining to causation and redressability has never been established. ${ }^{29}$

Even the degree of certainty with which causation and redressability must be proved is still contested. Professor Davis has argued that "an identifiable trifle is enough ...." ${ }^{30}$ The Supreme Court flirted briefly with Professor Davis's formulation in United States $v$ SCRAP, ${ }^{31}$ but never formally endorsed it. Rather, the Court requires that plaintiffs demonstrate a "substantial likelihood" of causation and redressability. ${ }^{32}$

As a further complication, standing includes more than the Article III minima; it "subsumes a blend of constitutional requirements and prudential considerations." ${ }^{33}$ The prudential considerations frustrate plaintiffs who seek to assert the rights of others or to litigate social grievances shared by citizens generally. ${ }^{34}$ Congress may, by statute, partially or entirely eclipse prudential limitations. ${ }^{35}$ However, a plaintiff must still meet the constitutional re-

${ }^{27} 397$ US at 153. See also Sunstein, 88 Colum L Rev at 1445 (cited in note 12).

${ }^{28}$ See, for example, Dellums v Nuclear Regulatory Comm'n, 863 F2d 968, 978 (DC Cir 1988) (refusing to defer to Congress's finding that the Anti-Apartheid Act would help end apartheid in South Africa).

${ }^{20}$ Framing a judicial inquiry is difficult because causation and redressability are questions of predictive, rather than historical, fact. Courts are accustomed to dealing with historical, evidentiary matters. See text accompanying note 92.

${ }^{30}$ Kenneth Culp Davis, Standing: Taxpayers and Others, 35 U Chi L Rev 601, 613 (1968).

s1 412 US 669, 689 n 14 (1973).

${ }^{32}$ EKWRO, 426 US at $44-45$.

${ }^{33}$ Valley Forge Christian College $v$ Americans United for Separation of Church and State, 454 US 464, 471 (1982).

${ }^{34}$ See, for example, Warth, 422 US at 498-99; Linda R.S., 410 US at 617-18; Allen, 468 US at 752-56; United States $v$ Richardson, 418 US 166, 176-77 (1974).

33 Warth, 422 US at 501 ("Congress may grant an express right of action to persons who otherwise would be barred by prudential standing rules."). For a discussion of pruden- 
quirement of a "distinct and palpable" injury to himself. ${ }^{36}$ Again, it is unclear why some courts allow Congress to exercise significant control over prudential limitations, while they ignore congressional statements that bear on causation and redressability. Whether a plaintiff's injuries will be redressed by judicial action seems as factually bound as whether a plaintiff presses a "social" grievance.

Criticized by Justice Brennan as a "dissembling enterprise,"37 standing remains "one of the most amorphous concepts in the entire domain of public law."38 Critics agree that the Court's standing test has failed to provide consistent results. Professor Davis characterized the Court's standing decisions as "permeated with sophistry";"s9 Professor Chayes regarded the standing formula as a ritualistic "litany," recited before "the Court [] chooses up sides and decides the case." $" 40$

These criticisms seem close to the mark. The standing "test" has more than once proved manipulable enough to grant standing where causation was charitably described as "attenuated."41 On other occasions, however, the Court has imposed so heavy a burden

tial standing requirements, see William A. Fletcher, The Structure of Standing, 98 Yale L J 221, 251-53 (1988).

s6 Warth, 422 US at 501.

37 Valley Forge, 454 US at 493 (Brennan dissenting). The Court's dissatisfaction with its own opinions on standing transcends ideological boundaries. Justice Rehnquist, in his opinion for the Court in Valley Forge, was only slightly more charitable than Justice Brennan:

We need not mince words when we say that the concept of "Article III standing" has not been defined with complete consistency in all of the various cases decided by this Court which have discussed it, nor when we say that this very fact is probably proof Id at 475 .

that the concept cannot be reduced to a one-sentence or one-paragraph definition.

38 Flast $v$ Cohen, 392 US 83, 99 (1966), quoting Hearings on S 2097 before the Subcommittee on Constitutional Rights of the Senate Committee on the Judiciary, 89th Cong, $2 \mathrm{~d}$ Sess 498 (1966) (statement of Professor Paul A. Freund).

30 Kenneth Culp Davis, 4 Administrative Law Treatise § 24:35 at 342 (West, 2d ed 1983).

${ }^{40}$ Abram Chayes, The Supreme Court 1981 Term - Foreword: Public Law Litigation and the Burger Court, 96 Harv L Rev 4, 22-23 (1982). For a summary of academic literature criticizing the Court's standing doctrine, see Fletcher, 98 Yale L J at 221 n 4 (cited in note 35).

'SCRAP, 412 US at 688. Then-Judge Scalia later caricatured the SCRAP plaintiffs' causation argument:

The suit was brought by a group of George Washington Law School students, who assertedly used park and forest areas, which areas assertedly would be rendered less desirable by increase of litter, which increase assertedly would result from decline in the use of recycled goods, which rise assertedly would be produced by the freight surcharge. And if that were not harm enough, the aggrieved plaintiffs also averred that each of them "breathes the air within the Washington metropolitan area, the area of his legal residence, and that this air has suffered increased pollution caused by the 
that "substantial likelihood" amounts to a requirement of virtually certain causation and inevitable redress. ${ }^{42}$ Some critics accuse judges of using standing to disguise ideologically motivated opinions about the merits of private plaintiff suits against administrative agencies. ${ }^{43}$ Standing is a constitutionally mandated limit on the judicial power. It would be ironic if its abuse actually enlarged judicial discretion to dispose of potentially meritorious claims.

\section{Division on the D.C. Circuit Over Congressional Findings And Separation of Powers}

\section{A. Center for Auto Safety $v$ Thomas}

Against this complex backdrop, the D.C. Circuit has heard many private plaintiff suits against federal agencies, and it has applied the standing test with uneven results. ${ }^{44}$ In 1988, the D.C. Circuit divided over a novel aspect of the standing issue in a rehearing en banc of Center for Auto Safety $v$ Thomas.5 The heart of the controversy was the extent to which courts should defer to congressional factual findings relating to causation and redressability. Sensing a danger to separation of powers, one wing of the court refused to defer to Congress's findings in the standing analysis. ${ }^{46}$ The likely result of such deference, it claimed, is illegitimate ex-

modified rate structure." . . Indeed, the court intimated, with respect to this governmental action "all who breath [the country's] air" could sue.

Scalia, 17 Suffolk U L Rev at 890 (cited in note 9) (footnotes omitted). See also Comment, Standing of Third Parties to Challenge Administrative Agency Actions, 76 Cal L Rev 1061, 1081 n 118 (1988).

42 For an extreme example, see Linda R.S., 410 US at 614-18 (denying standing to an unwed mother challenging a Texas law that provided for criminal sanctions against parents who failed to provide a minimum level of child support because she failed to show that the father would pay child support rather than go to jail). Professor Sunstein characterized the Court's response in Linda R.S. as "odd," asserting that "the very existence of the criminal law attests to the seemingly obvious assumption ... that criminal penalties influence behavior." Sunstein, 88 Colum L Rev at 1452-53 (cited in note 12). See also EKWRO, 426 US at 42-44 (Court denied standing to groups representing indigents who were challenging IRS actions that permitted certain hospitals to retain tax exemptions while denying low cost treatment to the poor; plaintiff's causation claim held "purely speculative" because the hospitals might choose to forego the tax savings rather than provide indigent services).

${ }^{43}$ See Comment, 76 Cal L Rev at 1062 n 3 (cited in note 41). See also Mark V. Tushnet, The New Law of Standing: A Plea for Abandonment, 62 Cornell L Rev 663, 663-64 (1977).

44 Compare City of Los Angeles v NHTSA, 912 F2d 478, 492 (DC Cir 1990) (threatened harm from global warming held sufficient for standing) with Dellums $v$ Nuclear Regulatory Comm'n, 863 F2d 968, 975-76 (DC Cir 1988) (harm from importation of uranium hexafluoride from South Africa deemed insufficient for standing).

45847 F2d 843 (DC Cir 1988), vacated 856 F2d 1557 (DC Cir 1988).

${ }^{48}$ Id at 863-87. This wing of the D.C. Circuit included Judges Douglas Ginsburg, Laurence Silberman, and James Buckley. 
pansion of the courts' Article III power to hear "cases and controversies" through rubber-stamp judicial treatment of inaccurate congressional findings. Another wing of the court, however, argued for deference on similar grounds. ${ }^{47}$ The real danger of expansion of judicial power, it asserted, arises when courts ignore valid congressional factfinding. They do so, on this view, at the risk of rendering unprincipled, factually suspect standing decisions. The import of these crucial separation of powers issues was apparent to at least one member of the court:

In the D.C. Circuit, the standing doctrine has indeed become a surrogate for profound differences about larger separation of powers questions. At the same time our skirmishes have immense and immediate practical implications for access to the courts to challenge major administrative actions. ${ }^{48}$

The petitioners in Center for Auto Safety $v$ Thomas, ${ }^{49}$ four nonprofit organizations that promoted energy conservation, sued to overturn EPA's downward adjustment of the Corporate Average Fuel Economy ("CAFE") standards." These downward adjustments were originally granted in response to auto manufacturers' assertions that changed testing procedures had unfairly caused the CAFE averages of their automobile fleets to decrease. ${ }^{\text {si }}$ The Center for Auto Safety petitioners disputed that changes in testing procedures entitled manufacturers to CAFE adjustments and claimed that these credits (1) impermissibly relieved manufacturers from liability for their failure to meet federal mileage standards, and

47 Id at 855-57. This wing of the D.C. Circuit included Judges Ruth Bader Ginsburg and Patricia Wald.

4s Patricia M. Wald, The D.C. Circuit: Here and Now, 55 Geo Wash L Rev 718, 723-24 (1987)

40 847 F2d 843 (DC Cir 1988).

so The original CAFE standards, promulgated under Title III of the Energy Policy and Conservation Act ("EPCA"), 15 USC $\$$ 2001-2012 (1982 \& Supp II 1984), required manufacturers to effectuate a $50 \%$ improvement in the fuel economy of their fleets by model year 1980 and to double efficiency by model year 1985. See Center for Auto Safety, 847 F2d at 845 (Wald concurring).

CAFE establishes a system of penalties and credits to encourage fuel efficiency. 15 USC $\S \S 2008(b)(1)(B)$ and 2002(1) (1988). Under CAFE's complex regime, all credits awarded or deficiencies assessed are subject to a three-year carryforward/carryback. That is, credit for exceeding CAFE's minimum fuel-efficiency standards in any model year covered by the program is set off against any deficiencies incurred during the three model years preceding or following. Deficiencies carry forward or back in like manner. 15 USC § 2008(b)(1)(B).

s1 See 48 Fed Reg 56526 (1983) (notice of proposed rulemaking); 49 Fed Reg 48024 (1984) (supplemental notice of proposed rulemaking); 50 Fed Reg 27172 (1985) (final rule). See Center for Auto Safety, 847 F2d at 846 (Wald concurring). 
(2) diminished the "manufacturers' incentives to develop and market a wider range of fuel-efficient vehicles."s2

Earlier, a unanimous panel had held that petitioners had standing. ${ }^{53}$ The full court, however, vacated the panel's opinion and granted rehearing en banc. ${ }^{54}$

On the rehearing, the D.C. Circuit divided evenly. A group of five judges led by then-Chief Judge Wald found that petitioners had standing. Noting that "only a 'substantial likelihood' that the allegedly unlawful action would cause such injury [was] required," ${ }_{55}$ Judge Wald asserted that "common sense and elementary economic logic ... . [as well as] congressional fact finding" proved that petitioners met the substantial likelihood standard. ${ }^{56}$

Judge Wald then analyzed the congressional factfinding pertaining to causation and redressability, writing that Congress fashioned the CAFE incentives to "encourage the manufacturers to exceed the [fuel efficiency] standards . . . ." Tht Therefore, "[t]here is no question but that the penalties and credits were designed as regulatory carrots and sticks to 'provide greater incentives for exceeding standards and ... provide greater flexibility to manufacturers in developing plans to meet standards." "58

In sum, Judge Wald concluded that "Congress' determination that its . . . system would in fact spur fuel-economy gains deserves considerable deference." ${ }^{\text {Bg }}$ The legislative history and CAFE's plain language show that Congress believed that manufacturers would exceed CAFE's mileage requirements. ${ }^{60}$ The court must defer, in Judge Wald's view, to this congressional finding. ${ }^{61}$

s2 847 F2d at 846-47 (Wald concurring). The petitioners asserted that the EPA ruling retroactively gave manufacturers credits for higher fuel economy ratings, saving an estimated $\$ 540$ million for General Motors and $\$ 245$ million for Ford. Id at 846 .

${ }^{63}$ Center for Auto Safety v Thomas, 806 F2d 1071 (DC Cir 1986). The panel also ruled for petitioners on the merits, stating that "[t]he EPA's decision to award manufacturers CAFE credits . . . and to refrain from debiting them for retroactive changes, removes substantial financial incentives to produce more fuel-efficient vehicles in the future." Id at 1075.

s4 Center for Auto Safety v Thomas, 810 F2d 302 (DC Cir 1987).

ss Center for Auto Safety, 847 F2d at 854 (Wald concurring).

ss Id at 855. Regarding injury-in-fact, petitioners' claim that lower CAFE standards raised the price of fuel-efficient cars was deemed a "classically cognizable economic injur[y]" within the class of harms recognized as injury-in-fact. Id at 850 .

${ }^{57}$ Id at 855, quoting Automobile Fuel Efficiency Act of 1980, HR Rep No 1026, 96th Cong, 2d Sess 19-20 (1980), reprinted in 1980 USCCAN 3845, 3858.

ss Id, paraphrasing HR Rep No 1026 at 19, in 1980 USCCAN at 3858-59.

69 Id at 856 .

so Id at 855-56.

61 Wald criticizes the dissenters because "in refusing to credit Congress' fact-finding, [they] blink a long line of decisions relying on such legislative determinations in the context of standing inquiries." Id at 856. 
Four judges led by Judge Buckley parted with the Wald opinion on causation and redressability. ${ }^{62}$ Judge Buckley contended that "petitioners must allege facts 'from which it reasonably could be inferred that ... there is a substantial probability that' in practical effect the [CAFE] provisions would have ... produc[ed] ... cars having a greater fuel efficiency. ..." ${ }^{63}$ Congress's belief that CAFE would spur technological advances could not, according to Judge Buckley, conclusively establish causation and redressability, ${ }^{64}$ because the lengthy development and marketing period for new automobiles, in his view, made it unlikely that EPA's adjustment would lead to lower-mileage cars than otherwise would have been produced. ${ }^{85}$ "Although Congress's understanding may affect the quantum of proof" that must be shown, the final decision is one for the courts. ${ }^{66}$ Otherwise, Judge Buckley warned, Congress could circumvent Article III "simply by making 'findings' concerning causation and redressability."

In a separate dissent, Judge Silberman asserted that petitioners demonstrated neither injury-in-fact nor causation and redressability. ${ }^{68}$ With regard to congressional findings, Judge Silberman agreed with Judge Wald that "Congress determined that the credit-penalty carryover system would in fact spur fuel-economy gains." ${ }^{69} \mathrm{He}$ argued, however, that this finding was irrelevant since petitioners "seek only a wider variety of 'fuel-efficient cars,' and

-2 Judge Buckley would have denied standing on injury-in-fact grounds to one of the four Center for Auto Safety petitioners. Id at 866-67 (Buckley dissenting in part). Judges Kenneth Starr, Douglas Ginsburg, and Stephen Williams joined Buckley's dissent.

63 Id at 870 (Buckley dissenting in part), quoting Warth $v$ Seldin, 422 US 490, 504 (1975).

64 Id at 874 (Buckley dissenting in part).

os Id at 872 (Buckley dissenting in part). This argument is based on events leading up to the manufacturers' request that EPA revise the CAFE standards. According to Judge Buckley, by July, 1985, when the EPA order issued, "it was clear that Ford and GM would fail to meet the . . 1987 and 1988 CAFE standards." Id at 871 . Since the opportunity to carry forward CAFE credits realized as a result of EPA's adjustment expired soon after the order issued, the manufacturers' incentive to produce fuel efficient cars subsequent to 1986 was unaffected. (The EPA order issued on July 1, 1985. To allow for production within the three-year period following model years 1984 and 1985, the model years covered by the EPA ruling, the companies had less than 18 months to incorporate improvements in their 1987 cars, and less than 30 months within which to incorporate improvements in 1988 models.)

Overturning EPA's order would likely not result in petitioners' desired fuel economy gains for model years 1987 and 1988. Judge Buckley concluded, therefore, that "as of the date petitioners brought their action, too little time remained for GM and Ford to earn credits through further technological improvements." Id at 872 (Buckley dissenting in part).

68 Id at 874 (Buckley dissenting in part).

67 Id.

ss Id at 876-87 (Silberman dissenting).

co Id at 885 (Silberman dissenting) (citations omitted). 
there is no congressional finding that raising the fleet average will generate increased consumer choice." 70 Thus, petitioners' claim that EPA's action would prevent development of a broader range of fuel-efficient cars ${ }^{71}$ had no relation to Congress's determination that CAFE would raise fleet fuel efficiency:

A manufacturer might raise its fleet average by raising the price of its less fuel-efficient cars, decreasing their sales and making consumers worse off. It might lower the price of existing fuel-efficient cars, or promote them in some other manner with no impact on available variety. Or it could boost the fuel efficiency of the lower end of its production spectrum, leaving untouched the more efficient cars that concern petitioners' members. ${ }^{22}$

Thus Congress's findings may help determine whether EPA's CAFE adjustment decreased fleet fuel efficiency. They are unrelated, however, to petitioners' claim that the ruling discouraged development of fuel efficient cars.

\section{B. Dellums v Nuclear Regulatory Comm'n}

In Dellums v Nuclear Regulatory Comm' $n{ }^{73}$ members of Congress, anti-apartheid groups, anti-nuclear proliferation organizations, an exiled black South African, and an unemployed American uranium worker sued to challenge the Nuclear Regulatory Commission's ("NRC") grant of import licenses for shipments of uranium hexafluoride mined in the Union of South Africa. Petitioners claimed that these licenses were granted in violation of the AntiApartheid Act. ${ }^{74}$

1. The core findings dispute.

Judge Silberman, now writing for the court, acknowledged that the Supreme Court's standing jurisprudence was "less than pellucid."7s Judge Silberman then proceeded to deny standing on injury-in-fact grounds to three of the four organizational petition-

\footnotetext{
70 Id.

${ }^{71}$ See id at 846-47.

72 Id at 886 (Silberman dissenting).

73863 F2d 968, 970-71 (DC Cir 1988).

74 Comprehensive Anti-Apartheid Act of 1986, 22 USC $\S 5001$ et seq (Supp IV 1986).

${ }^{75}$ Dellums, 863 F2d at 971.
} 
ers. ${ }^{76} \mathrm{He}$ then denied standing to the fourth organizational petitioner and the individual petitioners on causation and redressability grounds. ${ }^{77}$ Petitioner Robert Chavez claimed that imported South African uranium hexafluoride caused him to be laid off from his mining job, and reduced his chance to regain employment. ${ }^{78}$ Judge Silberman quickly dismissed this claim, asserting that "the decline in the [uranium mining] industry has been attributed to cancellations and delays in the construction of domestic nuclear reactors and to other developments .... The string of tenuous inferences that petitioners have offered simply does not demonstrate the causal nexus between Chavez's injury and the NRC's orders." $" 79$

Petitioner Henry Isaacs, an exiled black South African, contended that NRC's orders "blunted the effectiveness of the AntiApartheid Act, which was designed to bring an end to apartheid." Although Isaacs's inability to return to South Africa without facing arrest and prosecution qualified as injury-in-fact, ${ }^{81}$ the court denied standing, asserting that the marginal change resulting from the addition of an NRC ban on uranium hexafluoride would not be the "proverbial 'straw that breaks the camel's back' and lead to the collapse of the apartheid system."

Nor was Isaacs's claim rescued by Congress's finding that the Anti-Apartheid Act would be an "effective means" to pressure the South African government. ${ }^{83}$ Judge Silberman refused to defer, insisting that although Congress "can provide legislative assessments which courts can credit in making standing determinations ... we have never as a court held that we are bound to accept a congressional appraisal of the effect of its product. Indeed, to do so would be to permit Congress, by legislation, to amend the Constitution." 84

76 The organizational petitioners were the American Committee on Africa, TransAfrica, Inc., The Washington Office on Africa, and The Nuclear Control Institute. Id at $970 \mathrm{n} 2$. The American Committee on Africa and the Washington office on Africa failed to allege a "distinct and palpable harm," while the Nuclear Control Institute "alleged no particular injury to its members." Id at 972 .

77 Id at 973-80. The individual petitioners were unemployed uranium miner Robert Chavez and exiled black South African Henry Isaacs. The fourth organizational petitioner was TransAfrica, Inc.

78 Id at 973 .

7. Id at 973-74.

Id at 974 .

si Id.

s2 Id at 976.

ss Id at 978, citing 22 USC $\S 5013$.

s4 Id (citation omitted). 
2. Article I legislative power vs. Article III judicial power.

In Dellums, Judge Silberman denied that congressional findings "either typically or in this case answer the same analytical question that the redressability component of Article III presents to us." 85 That is, Congress may legislate knowing that the means they choose are unlikely ever to effectuate the ends they seek: Congress is not restrained by any constitutional requirement that its scheme will have a "foreseeable proximate effect on any specific individual." ${ }^{86}$ Thus, because Congress's findings were neither compelled nor disciplined by the Constitution, Judge Silberman argued that they should not be accorded deference in the standing inquiry.

The facts of Dellums provide an apt example for this argument. Congress passed the Anti-Apartheid Act hoping to affect, over a long period of time, the behavior of a nation. Congress was not required to determine that the Act was "substantially likely" to bring about this change. Thus, for Judge Silberman, whether the use of the court's power to deny the import licenses is "likely (let alone substantially likely) to cause an end to apartheid so as to redress Isaacs' injury," is purely a judicial question. ${ }^{87}$

In her dissent as to standing, Judge Ginsburg argued that Congress's comparative factfinding advantage overcame any danger of illegitimate findings. Once Congress has plausibly determined that a certain action will achieve a given end, courts should not speculate to the contrary. ${ }^{88}$ Moreover, "[d]eference should be at its zenith," she argued, "when Congress has predicted that a foreign country will react to sanctions in a particular way, because such a prediction is outside the judiciary's expertise."

Judge Ginsburg disagreed with the court's contention that deference to congressional findings would allow Congress to amend the Constitution by legislation. ${ }^{\circ 0}$ Deference, she maintained, does not mean that courts are "bound to accept anything and everything Congress labels its findings." How Hover, because "the redressability inquiry involves a question of predictive fact regarding matters outside the realm of judicial expertise," courts should dis-

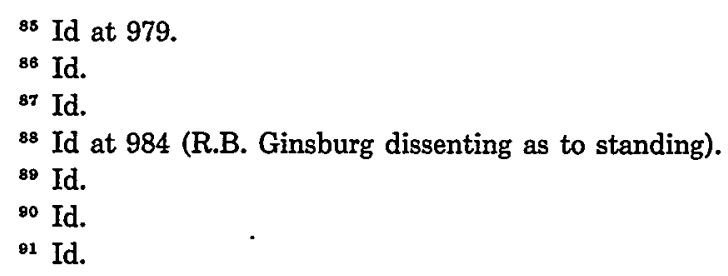


regard congressional findings "only upon a showing that Congress' judgment does not stand the test of rationality."

\section{City of Los Angeles $v$ National Highway Traffic Safety} Admin.

In City of Los Angeles $v$ National Highway Traffic Safety Admin., ${ }^{\text {gs }}$ the cities of Los Angeles and New York, the State of California, and several public interest groups, including the Natural Resources Defense Council ("NRDC"), used the National Environmental Policy Act ${ }^{94}$ to challenge NHTSA's decision not to prepare environmental impact statements ("EIS") covering CAFE standards for automobile model years 1987 through 1989. Writing for the court, Judge Douglas H. Ginsburg found that the municipal and state petitioners had standing. These petitioners' injuries arose from the increased smog that allegedly resulted from NHTSA's ruling, which, it was claimed, made it more difficult for these petitioners to comply with the Clean Air Act.95 Judge Ginsburg approved these claims, finding the injuries traceable to the decision not to prepare an EIS. ${ }^{96}$ Further, this injury was redressable because CAFE's carryforward/carryback provision meant that if the court were to vacate NHTSA's decision and order promulgation of an EIS, the agency's decision could still affect the marketing and production of new cars. ${ }^{97}$

Judge Ginsburg dissented, however, on the issue of NRDC's standing, where he voted to deny standing on redressability grounds. ${ }^{98}$ NRDC failed to show, he argued, that "but for the particular [challenged] governmental action . .., the injury would abate." "99 That was so because "[NHTSA's] decision appears to be but an insignificant tributary to the causal stream leading to the overall harm [global warming] that the petitioners have alleged."100

92 Id.

os 912 F2d 478 (DC Cir 1990).

os 42 USC $\S 4332$ (1988). The Automobile Efficiency Act of 1980, Pub L No 96-425, 94 Stat 1821, primarily codified at 15 USC \$§ 2001 et seq (1988), makes 27.5 miles per gallon the presumptive CAFE standard for automobile model year 1985 and thereafter. The Act authorizes NHTSA, however, to set a different standard, not lower than 26 m.p.g., for any model year in which 'the maximum feasible average fuel economy level' for that year is lower than 27.5 m.p.g. 15 USC $\S 2002(a)(4)$.

2s City of Los Angeles, 912 F2d at $484-86$. See 42 USC $\$ \S 7401$ et seq (1988).

8 Id at 485 .

27 Id. See note 50 for an explanation of CAFE's carryforward/carryback structure.

28 Id at $482-84$.

Id at 484, quoting Dellums, $863 \mathrm{~F} 2 \mathrm{~d}$ at 980.

$100 \mathrm{Id}$. 
Writing for the court on NRDC's standing, then-Chief Judge Wald disputed Judge Ginsburg's assertion that the NHTSA's ruling played a negligible role in causing global warming. ${ }^{101}$ First, Judge Wald contended that "NRDC need only show-and it did-that an EIS would redress its asserted injury, i.e., that any serious effects in global warming will not be overlooked." ${ }^{102}$ NRDC need not show what Judge Ginsburg demanded, that cancelling NHTSA's CAFE rollback would significantly alleviate global warming.

In any case, Judge Wald asserted that "we have previously rejected similar arguments to those NHTSA now raises."103 Harkening back to Center for Auto Safety, Judge Wald reasoned that just as the court respected Congress's determination that CAFE standards would encourage automobile fuel efficiency, the court must also conclude that NRDC's injury could be redressed by the preparation of an EIS on global warming. ${ }^{104}$

\section{United Transportation Unionv Interstate Commerce Comm'n}

In United Transportation Union, ${ }^{105}$ petitioner sought to overturn the Interstate Commerce Commission's decision allowing officers and directors of the nation's sixteen largest rail carriers to create interlocking directorates without prior approval under $\S 11322$ (a) of the Staggers Rail Act of $1980 .{ }^{106}$ The United Transportation Union ("UTU") claimed that railroad workers "st[ood] to be hurt" by the "unauthorized control and manipulation of carriers" and by "the financial wrecking of rail carriers" that UTU envisioned as the likely result of interlocking directorates. ${ }^{107}$

Writing for the court, Judge Silberman denied standing, asserting that "we see no reason-and the petitioner offers us none-to credit the proposition that an interlocking directorate ... will damage, let alone lead to the 'financial ruin' of a carrier."108 Nor did congressional findings stating that interlocking directorates lead to the ruin of railroads change this conclusion, he argued, for Congress may decide to pass legislation based on only a slim

101 Id at 492.

102 Id at 499.

$103 \mathrm{Id}$.

104 Id.

10s 891 F2d 908 (DC Cir 1989).

${ }^{108}$ Id at 909. The cited statute is part of the Staggers Rail Act of 1980, Pub L No 96448, 94 Stat 1895, codified at 49 USC $\$ \S 10101-11917$ (1988).

${ }_{107}$ United Transportation Union, $891 \mathrm{~F} 2 \mathrm{~d}$ at 913.

108 Id at 913-14 (emphasis in original). 
chance that collusion and bankruptcies in the railroad industry could be traced to interlocking directorates. ${ }^{109}$

Judge Silberman thus refused to defer to Congress. He insisted, however, that there was ample reason to refuse to defer in United Transportation Union without expressly deciding whether deference to congressional findings was ever, in other circumstances, proper. ${ }^{110}$

In her United Transporation Union concurrence, Judge Ruth Bader Ginsburg renewed her dispute with Judge Silberman, asserting that "Supreme Court jurisprudence for a half century or more has cautioned judges to defer to economic and social prescriptions, proscriptions, and predictions by elected representatives, so long as one can posit a rational basis for the legislative determination."111 Therefore, "deference to rational congressional predictions no more charters Congress to amend article III than deference to the legislators' rational policy judgments allows Congress to amend substantive constitutional constraints on its authority."112 The issue, then, was "whether courts start their inquiry with an initial bias in favor of the disposition of a co-equal branch, or whether they ... must be 'convinced' that the legislature's judgment is not only reasonable, but right."113

To support her argument, Judge Ginsburg returned to the lodestone of her concern with deference to congressional findings: separation of powers in the administrative state. Failing to defer to Congress's findings, she asserted, "brigad[es] article III . . . [and] effectively exalt[s] it over other constitutional constraints on legislative action." 114 This permits Congress to place a broad category of measures in the hands of administrators, while denying courts the ability to review significant administrative agency decisions. Judge Ginsburg feared that a de novo judicial review of causation, isolated from Congress's findings, would allow executive officers

109 Id at 916.

110 Id at 918. Judge Silberman asserted that he did not have to resolve the deference issue because (1) Congress's 1914 assessment as to the possible causal connections between interlocking directorates and railroad failures was outdated, and therefore deference to this determination would fail a test of rationality and (2) interlocking directorates formed with the blessing of the ICC over the past 40 years manifested no evidence of railroad failure resulting therefrom. Id.

11 Id at 920 (R.B. Ginsburg concurring).

112 Id.

113 Id.

114 Id. 
and agencies to "reign supreme, unchecked by the safeguard of judicial review."115

III. Standing Firm: How Deference to Congressional Findings In The Standing Analysis Keeps Faith With SeParation of Powers

The findings debate in the D.C. Circuit has produced more heat than light. However, it is possible to untangle the various arguments for and against deference, and to show how deference makes the standing analysis both more practical and consistent with the separation of powers.

\section{A. Separation of Powers: The Core Deference Dispute}

Center for Auto Safety and its progeny evidence a struggle between two conceptions of separation of powers. The Wald-R.B. Ginsburg wing ${ }^{116}$ of the D.C. Circuit asserts that deference to congressional findings on causation and redressability avoids entanglement in complex factual questions that Congress has already considered. In the Center for Auto Safety context, for example, the Wald-R.B. Ginsburg wing argues that due to the complexity of CAFE's carryforward/carryback structure, courts should not "override congressional factfinding and substitute [their] own predictions." 117 Treading such uncertain ground, judges should pay defence to congressional findings.

On the other hand, the Buckley-Silberman wing ${ }^{118}$ of the D.C. Circuit maintains that standing is not like economic or social legislation, in that it is rooted in Article III. Thus, deference to congressional findings endangers separation of powers: conscious of their judge-given power to control the standing analysis, Congress might make "findings" to circumvent the constitutional requirement.

B. Injury-in-fact vs. Causation and Redressability

Whether deference would encourage unauthorized amendment of Article III is not, as Judges Silberman and Buckley suggest, evi-

\footnotetext{
${ }^{125} \mathrm{Id}$ at 920.

${ }_{116}$ The "Wald-Ginsburg" wing includes Judges Patricia Wald and Ruth Bader Ginsburg.

117 Center for Auto Safety v Thomas, 847 F2d 843, 856 (DC Cir 1988).

${ }^{118}$ The "Buckley-Silberman" wing includes Judges James Buckley, Laurence Silberman and Douglas H. Ginsburg.
} 
dent. Indeed, the Buckley-Silberman approach admits several telling objections. First, Congress may establish injury-in-fact through the creation of a legal right. ${ }^{119}$ Thus, according to Justice Scalia, "[the] existence [of injury-in-fact] in a given case is largely within the control of Congress." 120

Deferring to Congress on injury-in-fact while simultaneously retaining tight judicial control over causation and redressability makes little sense. Congress may uniquely determine injury-in-fact because its very definition - an actual, "individuated harm ... of a tangible, concrete nature"121_becomes a tautology once Congress creates a statutory right. As Center for Auto Safety demonstrates, however, Congress's factual findings on causation and redressability also rest on complex legislative determinations that courts have little capacity systematically to assess or improve upon.

Moreover, while courts often deal with issues of causation and redressability in private-law actions, fundamentally different concerns surround these determinations in a public-law context. Private-law causation and redressability involve the actions of discrete individuals, and the likely effect of specified remedies on litigants actually before the court. Public-law causation and redressability, however, often involve the actions of governments, or classes of litigants, who may not be before the court or amenable to close control. As a result, courts are less able than legislatures, in the aggregate, to determine causation and redressability in public-law actions. Thus, from a purely technocratic perspective, courts should defer to congressional findings on causation and redressability. The following sections argue that deference is not only technocratically superior, but constitutionally preferred.

C. The Commerce Clause and Section 5 of the Fourteenth Amendment: Constitutional Foundations for Deference?

The Buckley-Silberman wing's refusal to defer to congressional findings on causation and redressability may be inconsistent with the Supreme Court's Equal Protection and Commerce Clause jurisprudence. The next two subsections will discuss these major constitutional provisions under which the Court has required deference to congressional factfinding.

\footnotetext{
11 See Comment, $76 \mathrm{Cal} \mathrm{L}$ Rev at 1083 (cited in note 41).

${ }_{120}$ Scalia, 17 Suffolk U L Rev at 885 (cited in note 9).

121 Tribe, American Constitutional Law $\$ 3-16$ at 114 (cited in note 10).
} 
1. Deference under the Equal Protection Clause.

In Katzenbach $v$ Morgan, ${ }^{122}$ the Supreme Court held that $\S 5$ of the Fourteenth Amendment ${ }^{123}$ empowered Congress to exercise discretion in determining the need for legislation to secure equal protection guarantees. According to Justice Brennan's opinion, $\S 5$ 's "positive grant of legislative power"124 required courts to uphold Congress's implementation of Fourteenth Amendment guarantees where "appropriate[]"125 - i.e., where they are rational. According to Morgan, then, legislation enacted under $\S 5$ of the Fourteenth Amendment should receive deference whenever rationally based-unless, of course, such legislation is based on a suspect classification, in which case the Fourteenth Amendment independently compels a "strict" level of scrutiny. ${ }^{126}$

Although Morgan does not directly address congressional findings on causation and redressability, there is an important connection: Congress's "implementation" of the Fourteenth Amendment guarantees rests on factual findings that identify discriminatory practices. Indeed, Morgan requires deference to congressional findings on questions that bear a striking resemblance to questions posed in the standing inquiry: Does a practice cause discrimination? Will a legislative scheme redress the discrimination caused? ${ }^{127}$

\section{Deference under the Commerce Clause.}

The Commerce Clause's guidance as to the outlines of the federal commerce power is as vague as Article III's "cases or controversies" limitation on the judicial power: "The Congress shall have Power ... To regulate Commerce with foreign Nations, and among the several States, and with the Indian Tribes." ${ }^{128}$ However, the Commerce Clause has been accepted as a grant of plenary authority to Congress, ${ }^{129}$ and "[e]ven activity that is purely intrastate in character may be regulated by Congress, where the activity, com-

${ }^{122} 384$ US 641 (1966).

${ }^{123}$ US Const, Amend XIV, $\S 5$ ("The Congress shall have power to enforce, by appropriate legislation, the provisions of this article.").

124384 US at 651.

128 Id.

${ }^{128}$ See United States v Carolene Products Co., 304 US 144, 152 n 4 (1938).

${ }^{127}$ Morgan, 384 US at 652-53, 656.

${ }^{228}$ US Const, Art I, \& 8, cl 3.

129 See Gibbons v Ogden, 22 US (9 Wheat) 1, 196 (1824). 
bined with like conduct by others similarly situated, affects commerce among the States or with foreign nations."130

Thus, the Commerce Clause mandates an essentially factual inquiry-the court must determine whether a given piece of legislation affects interstate commerce. In this context, the Court has been content to rely heavily on congressional determinations of what "affects" interstate commerce:

A court may invalidate legislation enacted under the Commerce Clause only if it is clear that there is no rational basis for a congressional finding that the regulated activity affects interstate commerce, or that there is no reasonable connection between the regulatory means selected and the asserted ends. ${ }^{131}$

In sum, courts defer to Congress's factual findings on whether a statute "affects" interstate commerce, despite the risk that deference to an erroneous finding would constitute an unauthorized amendment of the Commerce Clause. The Supreme Court is content to guard against this possibility through a rationality test, which is sensible given the alternative - an unguided judicial inquiry into what "affects" interstate commerce. Through deference, courts seek to ensure that the fuzzy outlines of the category of regulations that "affect" interstate commerce are determined by the body that has constitutional authority to assess the nature and effect of broad legislative schemes. ${ }^{132}$

Public-law standing, especially causation and redressability, presents a similarly diffuse set of judicial questions. The causal skeins of broad, remedial statutes are often hopelessly tangled. Litigants' interests may defy precise definition. ${ }^{133}$ Indeed, inconsistency has been a hallmark of the development of standing law, both in the Supreme Court and the D.C. Circuit. Perhaps the clearest message emerging from this confusion is that public-law standing is simply too unwieldy for the courts to manage alone. A division of labor is needed.

Initially, then, Article III's structural similarity to the Equal Protection and Commerce Clauses recommends similarly deferen-

130 Fry $v$ United States, 421 US 542, 547 (1975).

131 Hodel v Indiana, 452 US 314, 323-24 (1981).

132 Hodel $v$ Virginia Surface Mining \& Reclamation Assn., 452 US 264, 283 (1981) ("the effectiveness of existing laws in dealing with a problem identified by Congress is ordinarily a matter committed to legislative judgment").

${ }^{133}$ Note the wrangling over the nature of the claim in Center for Auto Safety, 847 F2d at 845-83. See text accompanying notes 49-72. 
tial judicial review. There remains, however, an apparently important difference between the the Equal Protection and Commerce Clauses and Article III's standing provisions: the former grant power to Congress, while the latter establishes, and limits, the judicial power. Does this difference matter? The next Section contends that it does not, for the Necessary and Proper Clause-like the Equal Protection and Commerce Clauses-represents a positive grant of power to Congress. This similarity implies that courts must defer to Congress's factual findings even where Congress is "carrying into execution," through its findings on causation and redressability, the powers of the judicial branch. ${ }^{134}$

D. Deference in the Standing Analysis Under the Necessary and Proper Clause

The Necessary and Proper Clause empowers Congress to "carry into execution" not only its own enumerated powers, but the powers of "any Department or Officer" of the government of the United States. ${ }^{135}$ This reveals that the Commerce Clause, § 5 and the Necessary and Proper Clause are importantly parallel-all three are "positive grants" of legislative power. Section 5 authorizes Congress to enforce the Fourteenth Amendment's prohibitions by appropriate legislation. ${ }^{136}$ The Commerce Clause authorizes Congress to regulate interstate commerce. The Necessary and Proper Clause grants Congress an even greater power: Congress is authorized to "carry[] into Execution ... all other Powers vested by this Constitution in the Government of the United States, or in any Department or Officer thereof."137

The formulae are essentially similar, but the Necessary and Proper Clause sweeps more broadly. While $\S 5$ and the Commerce Clause are limited grants of congressional power, the Necessary and Proper Clause allows Congress to "carry into execution" the enumerated powers of all three branches, including Article III's standing provisions. Congress, then, has the power to "carry" the standing inquiry "into execution" with a reasonable assessment of causation and redressability. The Necessary and Proper Clause eliminates any principled distinction between Congress's attempts to define the boundaries of its own enumerated powers-through, for example, findings that determine what "affects" interstate com-

\footnotetext{
${ }^{134}$ See text accompanying notes $135-38$.

135 US Const, Art I, \$8, cl 18.

${ }^{136}$ US Const, Amend XIV, § 5. See also Morgan, 384 US at 652-55.

237 US Const, Art I, § 8, cl 18.
} 
merce or what is "appropriate legislation" to implement the Fourteenth Amendment-and similar attempts to define the powers of the other branches.

In sum, the Necessary and Proper Clause indicates that Congress is under no constitutional disability when it makes findings concerning the scope of the power of another branch. Thus, the Necessary and Proper Clause extends the Equal Protection and Commerce Clause analogy to standing, and suggests that courts should defer to congressional findings in most instances where Congress exercises its power under that clause, limited only by the strict scrutiny rationale set out in Carolene Products. ${ }^{138}$

E. The Chevron Principle and Congressional Findings: A Technocratic, New-Deal Foundation for Deference?

Cheuron v Natural Resources Defense Council ${ }^{139}$ may also cut in favor of deference to congressional factfinding in the standing analysis. In Chevron, the Court established that when a court reviews an agency's construction of a statute which that agency administers, it must first determine "whether Congress has directly spoken to the precise question at issue." 140 If the statute is unambiguous, "that is the end of the matter; for the court, as well as the agency, must give effect to the unambiguously expressed intent of Congress." ${ }^{141}$ If, however, the court determines that Congress has not directly addressed the precise question at issue, the court should not impose its own construction of the statute, as would be necessary in the absence of an administrative determination. Rather, "the question for the court is whether the agency's answer is based on a permissible [rational] construction of the statute."142

Chevron's explicit holding - that an administrative agency's rational interpretation of an ambiguous statute is entitled to deference-rests on a conception of separation of powers and of policymaking that is embedded in the post-New Deal administrative state. Chevron, asserts Professor Sunstein, "embodies ... a plausible reconstruction of congressional desires and a sound understanding of the comparative advantages of agencies in administer-

\footnotetext{
1s8 304 US at $152 \mathrm{n} 4$.

1s9 467 US 837 (1984).

140 Id at 842 .

141 Id at 842-43.

${ }^{142}$ Id at 843.
} 
ing complex statutes." ${ }^{143}$ More controversially, Chevron may recognize that the interpretation of laws is importantly factual-"a question of policy as much as it is one of law."144 By this view, agencies are uniquely well situated to interpret ambiguous statutes, because agencies are superior policymakers (compared to courts), and agencies are at least indirectly accountable to voters through the President. ${ }^{145}$ Thus, Chevron embodies both a "technocratic" and a "separation of powers" principle. In combination, these principles imply that Congress intended statutory ambiguities to be treated by the courts as positive grants of agency discretion.

Although congressional findings are not explicitly addressed in Cheuron, if the case does represent a post-New Deal reconception of separation of powers, then it bears directly on the question of deference to congressional findings in the standing analysis. The argument, unfortunately, is tortuous. First, Congress is institutionally more capable than the courts to undertake the massive, complex factual investigations that bear on causation and redressability. This is even more true in public-law standing, where broad, remedial statutes present horrifically complex causation and redressability problems. Chevron's technocratic principle must commend these policy judgments to Congress. Further, Chevron's dismantling of the law/policy dichotomy reveals that a court's findings on causation and redressability are equally as steeped in policy as are agency interpretations of law. Thus, if policymaking is implicated in the factual findings underlying causation and redressability, then Cheuron's separation of powers principle directs this power to the most accountable institution-Congress, in this context. Chevron articulates a vision of separation of powers that accounts for changed conditions after the New Deal: This vision contemplates a reallocation of power, away from courts and to the emergent agencies and their patron and overseer, the Congress.

${ }^{143}$ Cass R. Sunstein, Law and Administration After Chevron, 90 Colum L Rev 2071, 2077 (1990).

$144 \mathrm{Id}$ at 2086.

14 Admittedly, the separation of powers element of this analysis does not fit well with independent agencies. 
F. Judge Silberman's Iconoclastic Arguments Against Deference

1. Does Congress care about causation and redressability?

Judge Silberman argued in Dellums that because Congress need not legislate according to a "substantial likelihood" of causation and redressability, courts must conduct a de novo standing inquiry to ensure that the Article III requirements are met. But just because Congress may choose to legislate without regard for the likely effectiveness of their action, it does not follow that judges should assume that Congress does so. Judge Silberman has adopted an improper baseline.

The attractions of a rational basis standing test are revealed by a close examination of the alternatives. Unquestioning acceptance of congressional findings as conclusive evidence of causation and redressability would dramatically expand the power of Congress. In essence, Congress would assume sole power to define the bounds of Article III. At the opposite pole, however, disregard of congressional findings is equally insidious for separation of powers. It would reduce the opportunity for private plaintiffs to police agency action (or inaction), and thereby act as "private attorneys general" to enforce what they perceive to be the will of Congress. Given the frequency of broad delegations to administrative agencies, Congress is often not able to remedy abuses of discretion legislatively. Given the increasing power of administrative agencies, their lack of direct democratic accountability, and the influence of the executive branch over these agencies, enforcement of congressional intent through "private attorneys general" is ever more important for separation of powers.

Deference to rational congressional findings strengthens separation of powers. Where a congressional finding makes a rational connection between the means prescribed and the ends sought, the test justifies deference to Congress's superior factfinding capacity and promotes actions by private attorneys general to check agency discretion. But where legislation is enacted on a clearly insubstantial basis of causation and redressability, a rational basis test no longer requires deference. The baseline assumption should be that Congress has considered causation and redressability, and that findings that appear to bear on those issues are valid. To assume 
otherwise implies examination of Congress's motives, an inquiry that the Supreme Court has repeatedly discouraged.146

Finally, Judge Silberman's argument may simply prove too much. It may be true that Congress often makes findings in complete ignorance of how these findings will affect the courts' inquiry into causation and redressability. But even if Congress ritually ignores causation and redressability, courts should still defer when Congress makes a clear statement indicating that it has done otherwise. There are two strong reasons for this conclusion. First, Congress makes lots of clear statements-for example, in Commerce Clause legislation-and courts have never agonized over deferring to them. ${ }^{147}$ Second, deference to clear statements on causation and redressability helps Congress focus on standing in general and on causation and redressability in particular. Thus, deference to clear statements helps ensure that Congress proactively considers these important constitutional values, before they become an issue for the courts.

2. Judge Silberman's "divide and conquer" approach: Causation and redressability problems created by statutes with manifold implementing provisions.

In Dellums, Judge Silberman made a separate and especially powerful argument against deference. Pointing to the AntiApartheid Act's manifold provisions, he argued that Congress did not consider the causation and redressability issues that would arise from the violation of any one provision, but only considered, if anything at all, the issues that would arise from the violation of the statute as a whole. ${ }^{148}$

This argument, though initially appealing, has disquieting implications. The global warming claim in City of Los Angeles is an apt example. ${ }^{149}$ Admittedly, the science of global warming is uncertain. In view of the seriousness of the effects of global warming, Congress may have decided to mandate a variety of anti-pollution

${ }^{148}$ See United States v O'Brien, 391 US 367, 383 (1968) ("It is a familiar principle of constitutional law that this Court will not strike down an otherwise constitutional statute on the basis of an alleged illicit legislative motive.").

${ }^{147}$ See Hodel v Virginia Surface Mining \& Reclamation Assn., 452 US 264, 277 (1981) ("when Congress has determined that an activity affects interstate commerce, the courts need inquire only whether the finding is rational"); Hodel $v$ Indiana, 452 US 314, 324 (1981) ("Congress was entitled to find that the protection of prime farmland is a federal interest that may be addressed through Commerce Clause legislation.").

14863 F2d at 975-76, 979.

149 See text accompanying notes $93-97$. 
provisions on a purely precautionary basis. Thus, by imposing a de novo judicial review of causation, courts reduce Congress's ability to create prudential statutes with manifold implementing provisions.

These "prudential" statutes are not uncommon.150 Where causal issues are unclear, Congress often enacts a variety of potential remedies, hoping that one will prove to be a magic bullet, or that a group of measures working together will be effective. De novo review will not stop Congress from legislating according to prudential standards. But it will sharply diminish the effectiveness of such legislation, by disallowing private suits for enforcement.

There is a simple way out of this, available even to courts that will not defer to Congress's findings on causation and redressability. Congress, in its judgment, should be able to legislate a lesser requirement of causation when the potential harm that the statute is enacted to avoid is great. Courts would then adjust their expectations and permit suits based on attenuated causal chains where Congress's findings indicate that the legislation at issue is prudential. To impose a strict judicial causation requirement on Congress's ability to legislate prudentially disables an important function of government that is in large part unique to Congress.

Special judicial deference to prudential legislation is, however, only a halfway measure. Judge Ruth Bader Ginsburg's Dellums standing dissent thoroughly rejected Judge Silberman's “'divide and conquer' approach," which, she objected, "renders the whole act immune to private action ...." As an empirical matter, Judge Ginsburg is likely correct-unless the NRC were to violate additional or more important provisions of the Anti-Apartheid Act, private plaintiff enforcement would be foreclosed. But as the Supreme Court indicated in Schlesinger $v$ Reservists Committee to Stop the $W a r,{ }^{162}$ there are legislative prescriptions whose violation causes no individual to suffer a distinct harm, but spread harm throughout the public generally. ${ }^{153}$ Correction of such generalized harm is left to the political branches. Nevertheless, Judge Ginsburg counters that "a statute with a unified objective but mul-

\footnotetext{
${ }^{180}$ For an excellent example, see Section II.B. (discussing the Anti-Apartheid statute in Dellums).

${ }^{181} 863 \mathrm{~F} 2 \mathrm{~d}$ at 987 (R.B. Ginsburg dissenting as to standing).

${ }^{162} 418$ US 208, 227 (1974) ("Our system of government leaves many crucial decisions to the political processes. The assumption that if respondents have no standing to sue, no one would have standing, is not a reason to find standing.").

${ }^{183}$ See id at 226-27; Dellums, 863 F2d at 987 (R.B. Ginsburg dissenting as to standing).
} 
tiple implementing agents should not be left judicially unenforceable ....."154

The facts in Dellums provide a strong argument for Judge Ruth Bader Ginsburg's opinion. It may be difficult at first to see how Congress's finding that the Comprehensive Anti-Apartheid Act's manifold provisions would help end apartheid addresses the relatively narrow issue of uranium hexafluoride importation. While it is problematic for separation of powers for courts to question the efficacy of entire legislative schemes, it strains common sense to imagine that banning uranium hexafluoride importation will have a significant impact on the policies of the South African government.

But if deference is problematic, Judge Silberman's alternative is worse. If the standing test requires that the misenforcement of one provision undermines an entire statutory scheme, then the standing inquiry will weigh heavily in favor of untrammeled agency discretion. Under Judge Silberman's regime, administrative agencies would essentially be left free to misenforce statutes up to the point where (1) multiple plaintiffs are able to join their claims to the extent that subversion of the entire statutory scheme is "substantially likely"; or (2) the agency violates so many provisions that the injury caused to a single plaintiff endangers the entire statute.

Thus, by isolating one statutory provision in the standing inquiry, Judge Silberman has effectively divided the Comprehensive Anti-Apartheid Act into many separate pieces of legislation. But this treatment of the Act fundamentally misapprehends Congress's legislative statement. Congress did not imagine that each provision of the Act, working in isolation, would effect a measurable change. Rather, it determined that a comprehensive package of antiapartheid measures, implemented and enforced as one over time, would do the job. Although Congress's findings address the Act as a whole, violation of any one of these measures undermines Congress's finding that the entire package will effect the desired change. Judge Silberman's "divide and conquer" strategy should not succeed.

3. Judge Silberman's illiberal rule of pleading.

On a different front, by insisting in Center for Auto Safety that petitioners "seek only a wider variety of 'fuel-efficient

${ }^{154}$ Dellums, 863 F2d at 987 (R.B. Ginsburg dissenting as to standing). 
cars," "155 Judge Silberman replaces the liberal rules of pleading of the Federal Rules of Civil Procedure ${ }^{156}$ with a special rule of narrow construction for standing. This crabbed reading of petitioners' complaint ignores what they were actually after-cheaper, more fuel-efficient cars.

Indeed, to require that petitioners identify particular models and components whose prices would be raised or whose availability would be diminished by EPA's ruling is, ${ }^{157}$ as Judge Wald rejoined, "attack[ing] a straw man."158 A fair reading of petitioners' complaint establishes simply that EPA's ruling would require petitioners' members to pay more money for the same fuel economy. Judge Silberman's stinting reading of petitioners' complaint "for the mere sake of appearance of specificity,"169 ignores the Supreme Court's warnings against mechanical application of the standing formula. ${ }^{160}$

\section{G. The Rational Basis Test in Practice}

It will be helpful to assess how deference to congressional findings would have affected the results in two cases: Dellums ${ }^{161}$ and United Transportation Union..$^{\mathbf{1 6 2}}$

In Dellums, a rational basis test would still ask whether importation of South African uranium hexafluoride had any measurable effect on the exiled black South African plaintiff's prospects for repatriation. The court would, however, begin with an initial disposition toward the validity of congressional factfinding bearing on that question. The party opposing standing would then bear the burden of demonstrating that Congress's findings were irrational. Given the courts' lack of expertise in foreign affairs, Congress's findings are likely to count in favor of the plaintiffs, but only in

${ }^{165}$ Center for Auto Safety, 847 F2d at 885 (Silberman concurring in part).

${ }^{158}$ See FRCP 8(f) ("All pleading shall be so construed as to do substantial justice.").

${ }^{157}$ Center for Auto Safety, 847 F2d at 877-79 (Silberman concurring).

188 Id at 849 (Wald concurring).

189 Id at 852 (Wald concurring).

180 See Pennell $v$ City of San Jose, 485 US 1, 7 (1988) ("application of the constitutional standing requirement [is not] a mechanical exercise, ... and [] when standing is challenged on the basis of the pleadings, we accept as true all material allegations of the complaint, and ... construe the complaint in favor of the complaining party"), citing Allen $v$ Wright, 468 US 737, 751 (1984) and Warth v Seldin, 422 US 490, 501 (1975). But see Sierra Club v Morton, 405 US 727, 734-36 (1972) (denying standing to an environmental group suing to overturn agency action allowing private development of a wilderness area on the ground that the group failed to allege that any of its members directly used the area).

${ }_{101}$ For a description of Dellums, see Section II.B.

162 For a description of United Transportation Union, see Section II.D. 
the standing analysis. On the merits, Congress's findings would be open to attack. In sum, Dellums would remain a close case. The effect of deference would be a more bounded standing analysis, one informed by Congress's factual findings.

On the other hand, Congress's findings in United Transportation Union likely would have been disregarded even under a rational basis test. In that case, Congress's findings regarding the destructive effect of interlocking directorates on the rail industry were made in 1914, when railroads enjoyed a commanding share of the interstate freight market. ${ }^{163}$ Since 1914, the share of interstate freight shipped by rail has declined significantly. ${ }^{164}$ Moreover, there is long-standing evidence of a widespread practice of interlocking directorates in the railroad industry, with no discernable ill effect. ${ }^{165}$ Thus, Congress's findings that interlocking directorates cause the financial ruin of railroads are outdated and presumably no longer rational. The denial of standing in United Transportation Union would not be disturbed.

\section{Conclusion}

Deference to congressional findings cannot replace a thorough reevaluation of standing law. Even when informed by rational congressional findings, the Court's standing jurisprudence will show the limitations inherent in its private-law pedigree. But in the present-day context of commonplace congressional delegation of broad rulemaking power to administrative agencies, the question of standing in private-plaintiff suits against administrative agencies should be straightforward. This is especially true because the Court's own jurisprudence sought to disentangle standing from the merits of particular claims. Heedless of this aim, courts have undertaken massive factual conjectures in pursuit of hazy notions of causation and redressability.

This Comment has argued that deference is a step back from the precipice: a modest but useful corrective to the Court's present standing test. The Constitution's structure (both in the Commerce Clause and in the Necessary and Proper Clause and its counterpart in Morgan's analysis of $\S 5$ of the Fourteenth Amendment), Chevron's technocratic principle, and Congress's acknowledged power to determine injury-in-fact all argue that courts should defer in the

${ }^{183}$ United Transportation Union v Interstate Commerce Commission, 891 F2d 908, 918 (DC Cir 1989).

164 Id.

165 Id. 
standing analysis to congressional findings that bear on causation and redressability. Deference is, moreover, recommended by a proper understanding of post-New Deal public-law standing and its implications for separation of powers. 
